\title{
Not A Partnership in Pepper, Coffee, Calico or Tobacco: Edmund Burke and the Vicissitudes of Colonial Capitalism
}

\section{Introduction}

Society is indeed a contract ... but the state ought not to be considered as nothing better than a partnership agreement in a trade of pepper and coffee, callico or tobacco, or some other such low concern, to be taken up for a little temporary interest, and to be dissolved by the fancy of the parties ... it becomes a partnership not only between those who are living, but between those who are living, those who are dead, and those who are to be born. Each contract of each particular state is but a clause in the great primeval contract of eternal society.

Edmund Burke, Reflections on the Revolution in France

Thus Edmund Burke set the dichotomous terms of his criticism of the natural jurisprudential theories of social contract, the extremities of which, he thought, glared in revolutionary France and suffused the radical Lockean sermons of Dr. Richard Price at home. The antithesis between the venal, temporary contract in commodities on the one hand, and the great primeval contract between generations, on the other, has conventionally been interpreted as a classical expression of the conservative, traditionalist, and organicist moorings of Burke's social and political philosophy. Obversely, it has also been construed to mark Burke's anxieties over the disintegration of the inherited social relations under the mercurial pressures of the rising commercial-capitalist forces, embodied in the ascendancy of moneyed interests. What has drawn no attention, however, is the specificity of the commodities subject to this contract which stands as the antithesis of Burke's "society" as such. Pepper, coffee, callico, and tobacco. The crass and fleeting contract that represented the mirror opposite and even the dissolution of the bonds constitutive of society was of a colonial-capitalist nature.

This essay argues that the notion of colonial capitalism can shine new interpretive light on Burke's intellectual career. While capitalism and colonialism are distinct historical and social phenomena, as I discuss below, there exist reasonable grounds to consider their historical entwinement and theoretical integration in a single, non-aggregative analytic field. In line with this composite interpretive framework, this essay brings together two prominent axes of analysis in the extant Burke scholarship. The first of these examines Burke's political economic works as situated in the shifting economic relations in Britain. 
The second focuses on Burke's writings and speeches on the British Empire, and especially on India, as the hermeneutic key for broadly interpreting his political thought. ${ }^{1}$ Unfortunately, scholarly works produced along these two axes, as internally variegated and insightful as they are, have not been in much productive exchange. Following Ann Stoler and Frederick Cooper's call to place the metropole and the colony in the same analytic field, ${ }^{2}$ this essay seeks to connect these two foci of analysis and read Burke's works on political economy and empire together.

I argue that when viewed through the lens of colonial capitalism, one can discern in Burke's thought perspicacious expressions of the historical tension between the liberal self-image of capitalism and its violent colonial entanglements in the late eighteenth-century British Empire. Burke's rhetorical flourish on the vicissitudes of the British Empire and his vituperation of the East India Company's economic policies in India articulate intellectual aporias that follow from attempting to accommodate coercive processes of capital accumulation in the colonies within a liberal cast of contractual freedom, equality, and civilized manners of a commercial society, which defined the self-conceptions of the metropole. The threat posed to the liberal-commercial self-image of Britain by the coercive processes of surplus extraction in India, I contend, can offer a new perspective on the tensions and ambivalences in Burke's thought. These tensions and ambivalences have been the object of much debate and disagreement in Burke scholarship, which I discuss below around the two "Burke problems."

I begin this essay with an overview of the two Burke problems and some theoretical remarks on colonial capitalism as an interpretive framework. I then proceed to a close analysis of Burke's “commercial ideal," where I reconstruct from Burke's writings a vision of political and moral economy that endorsed the pursuit of material interest, an ethos of productivity, and self-regulating markets. Most importantly, Burke prescribed a wall of separation between political power and economic transactions, which sustained legal equality and contractual freedom that were indispensable for public utility and equity. While Burke sanctioned capital accumulation in the liberal, metropolitan self-image of commerce as a voluntary and mutually beneficial relation, this image was profoundly challenged by the colonial expropriation and exploitation of India. The third section constructs a detailed inventory of the colonial 
inversions of the commercial ideal. In the fourth and last section, I argue that an attentive reading of Burke's indictment of the East India Company policies indicates that such inversions arose from tendencies inherent in the commercial ideal itself. Burke's attempt to salvage the liberality of commerce hinged on the containment of its colonial inflections, which threatened to disclose the unsettling propensities of self-interested exchange and the profit motive. Burke's inveterate denunciation of Company rule in India can be understood as an attempt to shore up the increasingly blurred distinctions between civilized commerce and unabashed plunder, between enlightened self-interest and unbridled rapacity, and between mercantile principle and political power. ${ }^{3}$ Against this theoretical background, I review Burke's post-1780 works as articulating an attempt to come to grips with colonial capitalism of the late eighteenth century. I conclude by drawing out the broader theoretical and methodological implications of the analysis presented here for political theory and intellectual history in general.

\section{The Two Burke Problems and Colonial Capitalism as a Frame of Analysis}

There is a sizeable literature that examines Burke's forays into political economy, and another, equally sizeable, that explores his concerns with the problems and conundrums of empire. These two literatures provide us with two "Burke problems," which serve as a useful departure point for this essay. The first "Burke problem" has as its stake the economic position of the author who once proclaimed that he has "made political oeconomy an object of my humble studies, from my very early youth to near the end of my service in parliament" (LNL, 159-60). ${ }^{4}$ One prominent strand of interpretation in this field depicts Burke as a proponent of modern economic relations that had emerged in eighteenth century England, and underscores his defense of the right to private property, pursuit of self-interest, and value of commerce. C. B. Macpherson provides the most assertive articulation of this position. Although not denying the conservatism of Burke's political thought, he maintains, "the market whose naturalness,

necessity, and justice [Burke] was celebrating was specifically a capitalist one." ${ }^{\circ 5}$ Macpherson's view of Burke finds resonance in unexpected quarters. J. G. A. Pocock, for example, who elsewhere criticizes Macpherson for causing 'unnecessary trouble ... by telescoping 'possessive' with 'accumulative,' and 
'accumulative' with 'bourgeois,", designates Burke a proponent of the Whig aristocratic government, which was identified with "the growth of the commercial society."7 Jerry Muller, by no means sharing Macpherson's Marxian commitments, paints Burke as a life-long Smithian champion of "capitalist economic development" and "free trade," and an opponent of the Speenhamland system of wage regulations. ${ }^{8}$ The latter point is endorsed by Gertrude Himmelfarb, for whom Burke's designation of labor as a commodity subject to the rules of commerce, and his austere stance on the "laboring poor" and poor relief, are indicators of his adherence to the principles of a competitive market economy. ${ }^{9}$ Even P. J. Marshall, who stresses the Ciceronian pedigree of Burke's thought, remarks that Burke was "very much a man of his time in his conviction that trade between equals could only be beneficial to both sides." 10

The commercial-capitalist image of Burke's economics is met with skepticism by those for whom the historically grounded, traditionalist parameters of Burke's intellectual world preclude commitment to modern market principles. This perspective is stressed by David Bromwich, who construes Burke's "attack on the psychology of commercial and scientific reason-giving" as an effort "to salvage the last of Britain's pre-capitalist morality of governance." ${ }^{11}$ Similar skepticism focuses on Burke's position on trade. For Ian Hampsher-Monk, Burke's well-known defense of the mercantilist Navigation Acts rests on "distinctly un-Smithian and very Burkean" grounds of custom, ${ }^{12}$ and strictly follows the purpose of severing the crown's link to colonial revenue and maintaining its financial dependence on parliament. ${ }^{13}$ Donald Winch highlights more generally the heterogeneity of Burke's economic thought, combining laissez-faire in the domestic labor market, unproductive consumption by the landed aristocracy, and the governmental regulation of trade. ${ }^{14}$

This interpretive spectrum also hosts a number of “ambivalent” Burkes. Isaac Kramnick's Burke is painfully stretched between the meritocratic values of the bourgeoisie (to which he belonged) and the prescriptive conventions of the aristocracy (whom he served). ${ }^{15}$ Bernard Semmel tries to resolve the conflicting tendencies in Burke's economic thought by ascribing economic conservatism to "early Burke" and economic liberalism to "late Burke,"16 a positioning which is emphatically rejected by Himmelfarb, 
who, instead, posits the tension in Burke's thought as representative of "the paternalists of the 1840s who cherished traditional social order with equal zeal as they did individualistic competitive economy."17

The second Burke problem revolves around Burke's efforts to retain and reform the British Empire, an issue on which he claimed considerable knowledge and celebrated himself, "most for the importance; most for the labor; most for the judgment; most for constancy and perseverance in the pursuit" (LNL, 159). Some scholars present Burke as a defender of empire, even though his reasons for such defense are weighed differently. Hampsher-Monk delineates "custom and shared culture" as the basis for a "continued imperial link," which, however, extended only as far as the Atlantic settler colonies. ${ }^{18}$ Especially when faced with the cultural alterity of the Indian dominions, Marshall contends, Burke invoked providence and an imperial duty to ensure the welfare of the imperial subjects: "a glowing vision of peoples, united through God's providence in a bond of protection and mutual benefit. ${ }^{19}$ " For Whelan, Burke conceived of empire as a vehicle of commercial grandeur and "progressive increase of improvement," especially in the New World, ${ }^{20}$ echoed by Daniel O'Neill's argument that Burke saw the British Empire as the redeemer of African barbarism and American savagery. ${ }^{21}$

Yet, Burke has also been hailed as a critic of empire. Uday Mehta and Jennifer Pitts, in an unexpected interpretive convergence, both maintain that Burke had an egalitarian appreciation of cultural pluralism, manifested most conspicuously in his sympathy for the Indian subjects under the rule of the East India Company. ${ }^{22}$ For Mehta, Burke's insistence on the contemporaneity of different experiences resisted metropolitan inclinations to map local difference onto temporal development and to authorize empire as the agent of civilization. ${ }^{23}$ In Pitts's account, Burke challenged exclusion and domination based on cultural and racial difference within the empire, and assailed the moral insularity of the British and their haughty disdain for the "barbarous Indian" through strategies of familiarization. ${ }^{24} \mathrm{O}$ 'Neill opposes such ascriptions of cosmopolitanism by tracing Burke's defense of the Indian society to the existence of an established aristocracy and institutionalized religion within it, which elicited the sympathy that Burke denied the natives of America and Africa. ${ }^{25}$ 
However, even Burke's purported anti-imperialist dispositions, and especially his efforts to impeach Warren Hastings, have been construed as serving the imperial cause. For Sara Suleri, the impeachment staged a spectacle of the "anxieties of empire," where Burke, an ambivalent accomplice in the colonial project, protected British colonialism "from being indicted for the larger ill of which Hastings was simply a herald. ${ }^{26}$ Nicholas Dirks sharpens Suleri's claim, and dubs Burke the "founding" figure of British imperialism for displacing the "scandal" from an inevitable element of empire to a mere “impediment" to good colonial government, and reclaiming empire as a "sacred responsibility" imbued with a moral mandate. ${ }^{27}$

Each of these interpretive controversies on Burke suffers from a basic theoretical shortcoming. The debate on Burke's political economic orientation, while valuable for its attention to the materiality of the social relations of reproduction, remains always within the confines of what Manu Goswami has aptly labeled "methodological nationalism," insofar it focuses on Britain as the exclusive context for explaining the development of commercial-capitalist forces. ${ }^{28}$ Britain's colonial possessions are consigned to an auxiliary status in this narrative of capitalist development, and treated as the passive recipient of capitalist relations that originated in England and diffused to the rest of the world. The debate on Burke's position on empire, indebted to insights generated by postcolonial studies, has the merit of underscoring the constitutive role of the colonies in the fashioning of metropolitan self-conceptions; however, the heavy culturalist orientation of analysis at best tends to underplay the economic calculations and incentives that played a crucial part in imperial expansion, ${ }^{29}$ and at worst leaves one with the impression that the British colonial enterprise was mainly ignited by the imperialist thrust inherent in liberal universals. As a result, Burke's economic and imperial works are often treated as addressing mutually indifferent questions.

An alternative perspective could be formulated by conceiving of the British imperial formation as the unit within which to consider the formation of commercial-capitalist relations, ${ }^{30}$ and the metropolecolony nexus as where the problems of political economy and metropolitan self-conception intersect. More specifically, I propose to analyze metropolitan political economic principles and their liberal values as integral to the self-image of Britain as "Protestant, commercial, maritime and free." ${ }^{31}$ To this end, I 
argue that Burke subscribed to a liberal self-image of Britain predicated on contractual freedom and equality under the rule of law, which was being openly tested by the imperial political economy of India, conceptualized here as "colonial capitalism." This reading can offer a new perspective on the two Burke problems by compelling us to think them together.

I understand the term colonial capitalism to describe the formative impact of colonial expansion on the development of global networks of capital accumulation, which are comprised of a heterogeneous array of relations of production and social control, most importantly, forms of unfree labor and unequal exchange. In a recent essay, Pitts includes among the "the British Empire's systemic injuries" "massive resource extraction, establishment of catastrophic systems of bonded labor, deindustrialization, entrenchment of 'traditional' structures of authority, and insertion of subsistence farmers into often wildly unstable global market systems." ${ }^{32}$ India's integration to global capital networks under the British rule involved the deindustrialization and peasantization of the Indian textile sector combined with the commercialization of agriculture, especially after the Permanent Settlement of $1793 .{ }^{33}$ While the dominant organization of production remained ostensibly non-capitalist, by the end of the eighteenth century peasant-based Indian agriculture had been enmeshed in the circuits of British and more broadly European capital. Indian peasants and agricultural laborers, working predominantly in the cultivation of cash crops like indigo, were bonded by forms of debt-peonage and forced to generate a surplus for the East India Company, landlords, financiers and agricultural entrepreneurs, in the form of tax, rent, and interest. ${ }^{34}$ Systemic exploitation of the peasantry primarily through non-market means, investment of agricultural tax revenues in financing exports to Europe and China, and the East India Company's manipulation of regional rivalries to expropriate local princes coalesced into a process of "colonial primitive accumulation," that is, extracting surplus from the subcontinent by means of legal and political force and absorbing it into global movement of capital, the epicenter of which was increasingly shifting to Great Britain. ${ }^{35}$ The marked illiberality of this process when judged by the bar of contractual freedom and legal equality, or put differently, the incompatibility between the colonial manifestations of capitalism in 
India and its liberal self-image embodied in ideals of British commercial society, offers us a vantage point for reconsidering Burke's critique of Hastings, and his effort to reform the Indian administration.

\section{Burke's Commercial Ideal}

The conviction that free pursuit of material interest, combined with a productive ethic of labor, would simultaneously improve personal fortunes and contribute to the overall wealth of society was a staple assumption of eighteenth century liberal political economic thought. ${ }^{36}$ This premise appeared in Burke's economic remarks as early as his Tracts on Popery Laws (1765) and persisted until his last publications, Letters on a Regicide Peace (1797). Lambasting the restrictive economic policies of antiPopery Laws in Ireland, Burke extolled the "desire of acquisition" as "always a passion of long views; confine a man to a momentary possession, and you at once cut off that laudable avarice which every wise state cherished as one of its first principles" (TPL, 477). Curtailing that laudable avarice by profit ceilings and short tenure terms in landed property resulted only in "famishing the present hour and squandering all upon prospect and futurity" and promoted a "thoughtless, loitering, and dissipated life" (TPL, 477). ${ }^{37}$ Three decades later, Burke revisited the "desire of acquisition," this time to defend moneyed property that floated the national debt during the Anglo-French War. This desire represented

a principle without which the means of their service to the state could not exist. The love of lucre, though sometimes carried to a ridiculous, sometimes to a vicious excess, is the grand cause of prosperity to all states. In this natural, this reasonable, this powerful, this prolifick principle ... it is for the statesmen to employ it as it finds it ... he is to make use of the general energies of nature, to take them as he finds them (3rdL, 347-8).

This assertion of self-interest as a "natural, reasonable, powerful, and prolific" principle and the source of accumulation of national wealth stripped it of its Aristotelian odium, pace the classical interpreters of Burke's political economy. In his 1780 "Speech on Economic Reform," aimed at improving the administrative structure of the British government, Burke boasted that his economic proposals were rooted not in "airy speculation" but "in real life, and in real human nature ... in the business and bosoms of men" (ER, 534). Properly managed, the desire to accumulate lodged in men's bosoms could be a 
universally beneficent force and it was incumbent upon the prudent politician to channel it towards, as Smith put it, "universal opulence., 38

The self-interest that Burke accepted and praised here was not the destructive urge derided by the classical-Christian tradition. It was rather akin to Adam Smith's "desire of bettering our condition, a desire which, though generally calm and dispassionate, comes with us from the womb, and never leaves us till we go into the grave." 39 That is to say, Burke's notion was already inflected by the transformation of destructive passions into the constant and predictable motive of accumulation, insightfully elaborated by Albert Hirschman. ${ }^{40}$ For Burke, as opposed to Smith and other Scottish Enlightenment thinkers, this transformation was indebted less to doux commerce than to the civilized manners fostered by Christianity and social prescription, which had over time attenuated the conquering spirit of arrogant nobility that characterized the ancient Britons. ${ }^{41}$ Thus rendered calm and dispassionate, self-interest implied two conditions: first, that the self-interested subject behave in a rational, settled, and most importantly, accumulative and future-oriented manner; secondly, following from the first, that labor and consumption be concentrated primarily, though not exclusively, in productive activities. ${ }^{42}$ The first of these conditions had its antithesis in the "thoughtless, loitering, and dissipated life" in Ireland (TPL, 477), while the second condition was contravened by the unproductive consumption that sustained the "unprofitable titles" of the royal household, which Burke targeted in his economic reform proposals (ER, 483). Even Burke's cherished nobility had to compensate for their "luxury and even their ease" by paying "contribution to the public; not because they are vicious principles, but because they are unproductive" $\left(3^{\text {rd }} \mathrm{L}, 349\right)$. Despite these fiscal considerations, however, Burke ascribed economically "unproductive" classes of nobility and clergy a crucial socio-political role in making possible the commercial domain in which productive consumption was to rule, a point I discuss below.

While security of property formed the backbone of the Whig worldview in general, Burke's thoughts on property articulated a particular socioeconomic vision, complete with assumptions and prescriptions about how the material and moral benefit of property could be maximized. It can be plausibly argued that Burke favored a capitalist type of private property, that is, large-scale enterprises 
worked primarily by wage-laborers. Burke not only extolled the private possession of land as a factor of production, but he also argued for the concentration of capital as much as possible. Burke provided the most unequivocal expression of this position in his posthumously published Thoughts and Details on Scarcity, which was originally crafted in 1795 as a memorandum addressed to the Prime Minister William Pitt the Younger. Designed to intervene in the parliamentary debates on high corn prices, minimum wage legislation, and amendment of the Elizabethan Poor Laws, the Scarcity essay comprises the clearest expressions of Burke's views on economic matters. There, Burke openly stated, “monopoly of authority $\ldots$ is an evil; but the monopoly of capital is the contrary. It is a great benefit, and a benefit particularly to the poor" (S, 132-3). The overall reasoning behind this endorsement was the familiar Smithian concatenation of the accumulation of stock, division of labor, increased productivity, expedited accumulation, universal opulence, and improved condition of the laboring population. Large-scale capitalist enterprises would enable their proprietors to keep afloat and invest at lower rates of annual profit, thereby providing sustained employment for laborers (S, 133).

While Burke composed the Scarcity essay late in his life, one can also catch early and unexpected glimpses of its capitalist market principles in Burke's "Speech on Economic Reform." This speech represented a chapter in Burke's (and more broadly Rockingham Whigs') ardent struggle against court influence, and its explicit objective was to preserve the independence of parliament by reducing the perceived political sway of the crown. ${ }^{43}$ The specific economic considerations that structured Burke's reform proposals were certainly strategic. However, perceiving them in the light of the other essays considered here suggests that they were not entirely conjunctural but belonged to a wider terrain of economic thinking. Burke's proposed methods for curbing royal patronage and political corruption included the sale of crown and forest lands on the grounds that such dispersed possessions "are of a nature more proper for private management, than public administration" (ER, 506). This call for the privatization of public lands becomes more intelligible if one bears in mind that Burke's political career coincided with the period of parliamentary enclosures that spanned roughly the century between 1750 and 1850 and consolidated large tracts of private property. One can conjecture that Burke had a favorable 
attitude on the whole enclosure process, given that he perceived in the enclosure of crown lands the same principles "upon which you have acted in private inclosures. I shall never quit precedents where I find them applicable" (ER, 506). ${ }^{44}$ Public lands thus sold were to be cheap enough to leave the purchasers with adequate "capital" for cultivating them. The principal revenue to be obtained from "these uncultivated wastes" would accrue not from the sales but from the "improvement and population of the kingdom," which required that the "unprofitable landed estates of the crown" be disposed of and "thrown into the mass of private property" (ER, 507).

Capitalist private property is incomplete without a labor force to work on it, and one finds strong assumptions and normative prescriptions of wage-labor in Burke's later writings. In the Third Letter on a Regicide Peace, Burke described the laboring classes of Britain as people who had nothing but their labor power to sell: "As to the common people, their stock is in their persons and in their earnings" and they were to be paid "according to the operation of general capital" $\left(3^{\text {rd }} \mathrm{L}, 352\right)$. Again, in the Scarcity essay, the labor power of the common people was referred to as "a commodity, like every other," "an article of trade ... subject to all the laws and principles of trade" (S, 122, 126). Burke's uncompromising commodity view of labor was compounded by his aloofness on the precariousness of the laborers' condition. Wages were determined not by the "necessity of the vender, but [by] the necessity of the purchaser" and whether one could obtain subsistence wages on the market was "totally beside the question in this way of viewing it" $(\mathrm{S}, 126)$. Intervening in the wage-contract was a direct and, in government's hands, an "arbitrary tax" that encroached upon property (S, 123, 126). Minimum wage or outdoor relief amounted to "trifling with the condition of mankind" for it pushed "those who must labour or the world cannot exist" to "seek resources ... in something else other than their own industry, frugality, and sobriety" $\left(3^{\text {rd }} \mathrm{L}, 355\right)$. That capital accumulation accrued from the surplus value generated by the industrious and sober wage-laborer was similarly unequivocal: "the labour, so far as that labour is concerned, shall be sufficient to pay the employer a profit on his capital" (S, 123). ${ }^{45}$ This relation of surplus transfer was couched in the language of a "natural and just" chain of subordination, as already noted by Macpherson, with enterprising capitalist-farmers at the top, descending to agricultural laborers, 
beasts of burden, and inanimate instruments $(\mathrm{S}, 125)$. The theological bent in Burke's view of the socioeconomic hierarchy, while setting it apart from Smith's more secular vision, in effect captured the social relations characteristic of eighteenth-century agrarian capitalism, namely, the triad of capitalist landlord, improving tenant, and wage laborer that had obtained in especially southern England. ${ }^{46}$ And, unlike Smith's political economy, Burke's religious language imbued economic inequality and distress with a fatalism that would be matched only by Thomas Malthus's theory of population. ${ }^{47}$

The other major pillar of Burke's commercial ideal was the justice of the free market. For Burke, the foundations of good government and just laws resided in equity and "general and publick utility" (TPL, 456). Left to its own operations, the market not only maximized public utility but also ensured that the transactions were equitable. Burke emphatically asserted in the Scarcity essay that the "market alone can settle the price" and does so with an astonishing "truth, correctness, celerity, and general equity" (S, 134). Burke's belief in the natural tendency of markets to convert self-interested behavior into societal prosperity went beyond Smith's metaphorical invisible hand and bordered on the providential maxim that "the benign and wise disposer of all things ... obliges men, whether they will or not, in pursuing their own selfish interests, to connect the general good with their own individual success" (S, 125).

The equity principle manifested itself first and foremost in contractual freedom based on the "great rule of equality" in commercial transactions (TPL, 456). This principle, which constituted the essence of the moral superiority of the free market over other forms of productive organization, was nowhere more explicitly asserted than in the Scarcity essay. There, Burke expressed his preference "to leave all dealing, in which there is no force or fraud, collusion or combination, entirely to the persons mutually concerned in the matter contracted for" $(\mathrm{S}, 123)$. Defending this preference with the reasoning that the contracting parties knew their interests and their particular circumstances better than any third party, Burke predicated the equity and therefore the validity of the contract exclusively on the volition of the contractors. If the parties were not "completely [masters of the intercourse], they are not free, and therefore their contracts are void" (S, 124). With each party looking to "all possible profit, which, without force or fraud, he can make," the contract implied compromise and identity of interest (S, 130). Most 
crucially, in labor contracts "it is absolutely impossible that their free contracts can be onerous to either party" (S, 124-5). While Burke had his misgivings about political theories of social contract, these passages indicate Burke's conviction that legal freedom and equality, and the categorical exclusion of deception and coercion, rendered economic contract a fair and morally elevated form of organizing material production and distribution. The complexity of Burke's philosophical principles and difficulty of interpolating them notwithstanding, his economic principles evinced overwhelmingly liberal attributes.

The providential aura with which Burke consecrated the market became even more salient when he later defended the "laws of commerce, which are the laws of nature, and consequently the laws of God" against the improvident hands of government (S, 137). Laissez-faire assumptions constitute the final aspect of Burke's vision of Britain as a commercial society. He was critical of government intervention in the market as detrimental to "general equity" insofar as it violated contractual freedom. "The moment that government appears at market, all principles of market will be subverted," and a "monopoly of authority" will emerge under the "appearance of a monopoly of capital" (S, 135). The economic role that Burke reserved for government conformed to a textbook description of laissez-faire. While government could "prevent much evil, it can to very little positive good" (S, 120); "the office of the judge cannot dictate the contract. It is his business to see that it be enforced" (S, 124). There could be "no authority on earth" to "judge what profit and advantage ought to be" (S, 125). Instead, the "the truly and properly public" function of the state was to maintain public peace, order, and safety: "Let Government protect and encourage industry, repress violence and discountenance fraud, it is all they have to do." $\left(3^{\text {rd }} \mathrm{L}, 355\right)$. Commercial affairs constituted a "department of things [that] manners alone can regulate. To these, great politicians may give a leaning, but they cannot give a law" (S, 144).

The most important premise in Burke's laissez-faire prescriptions was to keep the market devoid of political power. In order for the efficiency and justice of the market to unfold, commerce and sovereignty, economy and politics had to remain strictly compartmentalized. This is not to suggest that political power was irrelevant to commerce. On the contrary, it fulfilled a fundamental role in establishing and maintaining the conditions under which the moral and political economy of commerce could survive 
and flourish. As seminally argued by Pocock and expanded upon by others, Burke embraced the Scottish Enlightenment conception of "commercial society" in a very unorthodox manner. He subscribed to commercial society as a socio-historical category that encompassed a specific set of social, political, economic, and moral characteristics that placed it at the terminus of the known historical development of human communities. He parted ways with the Scotch philosophers, however, on the direction of the causal chain. Whereas Adam Smith, William Robertson, John Millar, and Adam Ferguson looked first and foremost to the commercial mode of subsistence to extrapolate polished manners and civil institutions, Burke prioritized the attenuating impact of organized religion and prescriptive hierarchy on manners. ${ }^{48}$ The relations characteristic of commerce could take hold only after a certain level of social stability, discipline and refinement was achieved through the exercise of power relayed by these emphatically non-economic institutions. This extra-economic element of power, which for Burke laid down the conditions of a complex modern economy, has been referred to as the "noncontractual basis of commercial society." ${ }^{49}$ Yet given Burke's as well as the Scotch philosophers' discrediting of social contract theories, a more apt designation would be the "noncommercial basis of commercial society." This noncommercial element marked the stakes of the specific relation between political power and commerce, and it is not coincidental that "force and fraud," the two virulent pathogens of commerce, frequently recurred in Burke's political economic writings. As long as government remained in its proper place, that is, in the margins of the economy, political power constrained force and fraud. If it penetrated the economy, political power became the instrument of force and fraud. Political power ought to form a shell that protected and ordered, through property rights and contract enforcement, the field of commercial transaction, yet should not bleed into that field. Precisely because it was the noncommercial condition of commerce, political power had to remain noncommercial.

In addition to the politico-legal medium, this constitutive noncommercial element surfaced in Burke's aesthetic appreciation of clergy and nobility, classes deemed to be economically unproductive and retrograde by Scotch political economists like Smith and Hume. ${ }^{50}$ Established church and aristocracy, respectively embodying the "sublime" and the "beautiful," fulfilled the essential role of inculcating in the 
populace the social discipline essential for the peaceful acquiescence of the lower orders to being governed by their betters. Sentiments of fear and love that these institutions inspired were what bound the "common people" to their station in life with volition and contentment, and formed a subtle yet strong fabric of "manners" that supported commercial relations (S, 144). ${ }^{51}$ For Burke, the object lesson in the constitutive link between, on the one hand, social discipline and order undergirded by organized religion and social hierarchy, and on the other, a complex and prosperous commercial economy was supplied by the French Revolution. The evisceration of French nobility and clergy was not only an appalling moral offence but also a tremendous economic catastrophe as it effectively undermined the "protecting principles" of "commerce, trade, and manufacture" (R, 130). Confiscation of church lands for backing up the new currency (assignats) epitomized the fatal shortsightedness that ruined for the sake of commerce its very noncommercial basis, and left in its wake a pack of "gross, stupid, ferocious, and at the same time, poor and sordid barbarians" $(\mathrm{R}, 131){ }^{52}$

In the next section, I demonstrate through a survey of Burke's reports and speeches on India that each and every one of the principles of this commercial ideal, or as Burke put it, "every just principle of commerce," was breached by the British rule on the subcontinent $\left(9^{\text {th }} \mathrm{R}, 306\right)$. Given that the commercial ideal was the primary prism through which Burke viewed and judged the British image, his fourteen-year long labors to reform the Indian administration can be read as a desperate attempt to shore up the frayed contours of the commercial ideal, and reinstate the boundaries between commerce and political power, economy and sovereignty, public and private. The East India Company's "merchant-sovereignty" that Burke came to despise represented the most offensive fusion of political power and commercial interest, and inevitably bred colonial violence and an economy of plunder. A related source of vexation for Burke was that the violators of the commercial principles in India had "come from a learned and enlightened part of Europe, in the most enlightened period of its time ... from the bosom of a free Country" (SOI, 315). On the colonial frontiers of British capitalism, civilized Britons rapidly jettisoned the manners and laws of commercial society, and turned into barbarous frontiersmen. Most importantly, a careful analysis of the specific terms in which Burke condemned the East India Company's exploits suggests that the 
source of effrontery to the commercial ideal was not a precommercial atavistic residue or the moral lapse of a few wayward individuals, but the very core of the commercial ideal itself. The natural desire to accumulate that animated the whole commercial society and powered the "great wheel of circulation" was the main source of the havoc in India. In the colonies, the truth of commerce showed itself to be piracy, the underside of self-interest was rapacity, and the arrival of civilization heralded barbarity.

\section{Colonial Inversions}

It would be fair to say that Burke did not hold grave concerns regarding the British ventures in India prior to early 1780s. In his 1781 "Speech on State of East India Company," he defended the chartered rights of the East India Company against the encroachments of the parliament and the crown, invoking the status of the Company charter as private property held sacred by historical prescription under the law of England. He became acquainted with the Indian affairs during his service on the Commons' Select Committee on East Indian Affair between 1781 and 1783. That Burke's position was still uncertain in 1781 is evidenced by his proposed Bengal Judicature Bill, which shielded the East India Company from governmental interference by curtailing the powers of the Supreme Court of Bengal. After two years of examining privileged information on Indian affairs, Burke's position had dramatically changed by 1783 . That year he spearheaded Fox's India Bill, which, if signed into law, would separate the political and commercial activities of the East India Company and place each function under parliamentary supervision. Burke justified this governmental intrusion into the Company charter by recourse to the "universal laws of morality" that determined the legitimacy of all chartered rights.

Burke's defense of Fox's India Bill responded to two major worries he had developed about the East India Company rule on the subcontinent. The first of these regarded the destructive impact of British economic policies in India, dramatically manifested in the 1769-1770 Bengal famine. The second targeted the corruption of British politics by "Indianism," a term Burke used to refer to a political "cabal" formed by the Company servants in India, the Court of Proprietors and the Court of Directors in London, and the most worrisome of all, a growing number of members of parliament who owed their seats to the money 
and influence of the Company and their allegiance to the Company's interests. Indianism crystallized in the figure of the "nabob," the Company agent returning to Britain with corrupt Eastern riches, like Paul Benfield who had made his fortune in Madras partially through funding local wars by usurious loans. The "Indian interest" expressed an amalgamation of political power and economic gain that profoundly unsettled Burke and pushed his colonial reform efforts to the point of obsession. These efforts reached spectacular proportions when he proposed in 1786 the impeachment of Warren Hastings, the Governor General of Bengal (1773-1784). Burke's speeches and writings between 1783 and 1797, especially his "Speech on the Fox's India Bill," (1783) the Ninth Report of the Select Committee (1783), "Speech on the Nawab of Arcot's Debts" (1785) and "Speech on Opening of Impeachment" (1788), offer an inventory of political corruption, economic misconduct, and moral degeneracy he perceived in the Indian government.

While the vagaries of British rule over a vast and culturally alien population might have remained the classical problem of a "free though conquering people," the agent of British rule was a mercantile company whose raison d'etre in India was material gain. The East India Company's newly acquired political power inflected its pursuit of commercial interests by opening up non-market opportunities for profit. As Burke put it, the East India Company’s "despotism" in India was not only "oppressive, irregular, capricious, unsteady," but more importantly "rapacious and peculating" (FB, 430). Putting power to profit rode roughshod over the commercial principles of property, legal equality, contractual freedom, and mutual benefit, sapping the foundations of a prosperous and just society in India. From 1783 onwards, Burke systematically declaimed the East India Company policies, and provided his audience with detailed accounts of the colonial plunder that they supported.

Burke's admonition of the Indian government in the Ninth Report of the Select Committee, the most comprehensive tract Burke ever wrote on the political economy of the Indian dominions, strongly suggests that he envisioned the commercial ideal as a normative grid that ought to have applied not just in Britain but in India as well. ${ }^{54}$ The "Mainspring of the Commercial Machine, the Principles of Profit and Loss" were to govern all economic dealings in India $\left(9^{\text {th }} \mathrm{R}, 241\right)$, and when the nawab (Mughal magistrate) of Bengal abolished all duties in a move to undercut the British abuse of trading privileges, Burke 
applauded this measure as a "forcible, simple and equitable" retaliation against the "oppressions of the monopoly" $\left(9^{\text {th }} \mathrm{R}, 244-5\right)$. Furthermore, Burke extolled the virtues of "rivalship" to redeem and reinvigorate the Indian manufactures $\left(9^{\text {th }} \mathrm{R}, 268\right)$, a notion that would later reappear as "market of competition" in the Scarcity essay (S, 135). Finally, inveighing against opium and salt monopolies, Burke declared the "unerring standard of the public [open, free, competitive] market" as the rule for Bengali economy $\left(9^{\text {th }} \mathrm{R}, 278\right)$. Burke therefore appears to have viewed the British Empire, complete with its settler colonies and dependencies, as the space in which "laws of commerce" should apply. The aegis of the British imperium would provide the political framework for the rule of law securing contractual freedom and equality in commercial transactions. Social and political heterogeneities notwithstanding, the British Empire constituted an economically homogenous space in which British subjects could be secured their property and their contracts. Burke's was a vision of "imperial commerce.",55

Commerce in India, however, was "imperious commerce" as the East India Company, both institutionally through the Council of Bengal and individually through its servants, deployed sovereign prerogative for material aggrandizement $\left(9^{\text {th }} \mathrm{R}, 244\right)$. The immediate effect was the abrogation of juridical equality in commercial transactions between the East India Company agents and the local merchants and producers. The British had been trading in India since the early-seventeenth century and always tried to wrest privileges and avoid duties in Bengal. However, until the middle of the eighteenth century, they had been compelled to run commercial transactions under the nominal authority of the Mughal emperor and the effectual jurisdiction of the nawab. ${ }^{56}$ After a string of military victories beginning with Plassey in 1756 and culminating in de facto rule in Bengal in 1765, the status of the British changed. While the East India Company strategically retained the nominal sovereignty of the Mughal emperor and the nawab, it effectively governed the province through its stranglehold on the revenue system. Burke was not convinced by this strategy: "the English are now a people who appear in India as a conquering nation" and any commercial dealing with them was a "dealing with power" $\left(9^{\text {th }} \mathrm{R}, 271\right) .{ }^{57}$ One of the first things the Company did with its newfound power was to eliminate all native intermediaries between the manufacturers and itself, thereby rendering its agents "magistrates in the Markets in which they dealt as 
traders" (FB, 427; $\left.9^{\text {th }} \mathrm{R}, 245,259\right)$. The stones of legal asymmetry had paved the road to "forced and exorbitant gains of a trade carried on by power" and invariably entailed the oppression and dispossession of the natives $\left(9^{\text {th }} \mathrm{R}, 246\right)$.

The natural correlate of the new legal inequality was the evaporation of contractual freedom, whereby coercion and extortion replaced volition, compromise, and mutual benefit overseen by an impartial judge. Under the East India Company rule, forms of bonded labor proliferated. Burke scornfully observed that the elimination of local middlemen and the "advances system" (whereby Indian producers were forced to accept credit in advance and mortgage their future labor, products, and even instruments of labor) reduced the Indian weavers to "virtual vassalage" under a "most violent and arbitrary power," and instituted "debt peonage" ( $\left.9^{\text {th }} \mathrm{R}, 259-60\right)$. A public and competitive market in credit, which could have freed the Indian producers from "debt bondage," was deliberately thwarted by East India Company policies $\left(9^{\text {th }} \mathrm{R}, 268-9\right)$. Adding insult to injury, laborers "defrauded" into debt bondage would be "delivered over like Cattle in Succession to different Masters, who, under Pretence of buying up the Balances due to their preceding employers, find Means of keeping them in perpetual Slavery" $\left(9^{\text {th }} \mathrm{R}, 290\right)$. Those who managed to avoid debt bondage found that they had no control over how they invested their stock. The monopoly powers of the Company in cash crops, especially opium, were used to force farmers to cultivate these crops instead of grain, even after the dearth and high costs of foodstuffs led to the 17691770 famine that decimated the population of Bengal $\left(9^{\text {th }} \mathrm{R}, 270-1,274\right)$.

Subversion of contractual freedom was compounded by the insecurity of property, which manifested itself in confiscations at all levels of the social hierarchy. Expropriation of the Indian nobility by the British was most dramatically described in Burke's "Speech on Almas Ali Khan" (1784), where he accused the Company of having invented "the crime of having money ... like the sin against the Holy Ghost in Christianity" (AA, 464-7). In this scheme, which Burke chronicled in detail in the Eleventh Report of the Select Committee, wealthy Indian nobles would be first accused of treason on fabricated and expedient grounds, and then punished by confiscation, sometimes accompanied by death. While the state's confiscation of property was an anathema to Burke's Whig sensibilities, its occurrence under the 
pretext of a legal trial ("the great criminal has the law in his hand." SOI 290) was a macabre travesty of justice, more execrable than the use of open, sheer force. Placing law in the service of plunder brought a disgrace upon the British nation, which Burke thought to "have better institutions for the preservations of the rights of men than any other Country in the World" (SOI, 352). Predation on property also struck Indian farmers and artisans, who were first indebted by the arbitrary pricing of the Company, and then visited by Company agents who acted in the capacity of lenders of usurious loans, assessors of the accruing debts, and finally bailiffs seizing the debtors' property $\left(9^{\text {th }} \mathrm{R}, 259-60\right)$. Finally, the lowest strata of Indian society, the ryots who worked the land of zamindars, were "ruined and made desperate" by extortionate taxes, not only on land (twice the rate in England), but also on such necessaries of life like salt under the British monopoly (AA, 463). The situation is starkly put in the "Speech on the Nabob of Arcot's Debts," which concerned the dispute between the Nawab of the Carnatic and his British creditors:

Every man of rank and landed fortune being long since extinguished, the remaining miserable last cultivator, who grows to the soil, after having his back scored by the farmer, has it again flayed by the whip of the assignee, and is thus by a ravenous, because a short-lived succession of claimants, lashed from oppressor to oppressor, whilst a single drop of blood is left as the means of extorting a single grain of corn (NAD, 532-3).

These were the "most miserable men," whose "blood withheld from their veins and whipped out of their backs" provided the "extortion, usury and peculation" on which the creditors and debtors fed (NAD, 496).

The aggregate effect of the political economy of plunder in India breached the mutual benefit principle of the commercial ideal. Commerce, conducted under the rule of a power that was itself a party in economic transactions, became a zero-sum game, whereby the enrichment of the British meant the impoverishment of Indians. In contrast to the Muslim conquerors before them, the British did not take responsibility for the dominions they conquered; instead, driven by an "insatiable lust for plunder," they carried away whatever they found available. Burke made the point in his "Speech on Fox's India Bill," his first parliamentary initiative to reform the Indian administration under the Fox-North coalition:

The difference in favor of the first conquerors is this; the Asiatic conquerors very soon abated of their ferocity, because they made the conquered country their own. They rose or fell with the rise or fall of the territory they lived in. ... But under the English government the order is reversed. The Tartar invasion was mischievous, but it is our protection that destroys India. It was their enmity, but it is our friendship" (FB, 401-2). 
Under the pretext of patronage and alliance, the East India Company devised fraudulent methods of coopting, indebting, and impoverishing local rulers and their dominions (FB, 396, 401-7) ${ }^{58}$ Indian riches thus obtained were siphoned out of the realm, making "the transport of its plunder ... the only traffic of the country" (FB, 427). After detailing the "deep, silent flow of wealth from the Carnatic," which he estimated to be 20 million pounds between 1760 and 1780, Burke would ask rhetorically, "what are the articles of commerce or the branches of manufacture which these gentlemen have carried thence to enrich India?" (NAD, 492, 494). These and other surveys of the systematic drain of wealth, or "the plunder of the East," prompted Burke to conclude emphatically, "commerce, which enriches every other country in the world, was bringing Bengal to total ruin" (SOI, 278, 428).

The fusion of political power and commerce reached its apex in the "revenue investment" system of the Company, which Burke examined in painstaking detail in the Ninth Report. After the Company obtained the revenue rights (diwan) of Bengal by the Treaty of Allahabad in 1765, it began to finance its Indian exports by the taxes it levied in that province. This constituted a "new system of trade, carried on through the medium of power and public revenue," which Burke clearly asserted was "not commerce" but “annual plunder," or "tribute" disguised as "investment" $\left(9^{\text {th }} \mathrm{R}, 221,223-6,231\right)$. Insofar as it was driven by narrow and immediate monetary concerns, the revenue investment system obscured the principle that the welfare of the natives and thus good governance was essential for the investment of capital, sustained profits, and steady tax revenue $\left(9^{\text {th }} \mathrm{R}, 221\right)$. Therefore, the "vast extraction of wealth" from India was maintained not, as it ought to have been, by the "improvement" of the country but by raising the land rents and by annulling the payments due to local powers, backed up in the last instance by the military force of the Company $\left(9^{\text {th }} \mathrm{R}, 231-2\right)$. Even more outrageously, despite its intensive pillage of the Indian wealth, the East India Company constantly teetered on the verge of bankruptcy, and had to be bailed out by the British government on more than one occasion. Mismanagement of Company funds and private embezzlement drained the coffers. The system of revenue investment had become a vehicle for remitting private fortunes to England at the expense of both British and Indian publics, vindicating Burke's 
conviction that there could not be public utility where there was no equity (FB, 448; $\left.9{ }^{\text {th }} \mathrm{R}, 235,242\right)$. "It is there the public is robbed," Burke declared, "in its army, in its civil administration, in its credit, in its investment which forms the commercial connection between that country and Europe." (NAD, 531).

Perhaps most troubling of all, violations of the free market, legal equality, and free labor were not occasional; their subversion was "regular, permanent, and systematical" (FB, 433) Such violations could not be attributed to the aberrant corruption of a few servants. Instead they flowed from the degeneracy of the state itself: "the hand of government, which ought never to appear but to protect, is felt as the instrument in every act of oppression" $\left(9^{\text {th }} \mathrm{R}, 272\right)$. The Indian administration represented a complete inversion of the functions that Burke ascribed to government in commercial society: instead of protecting property, it confiscated; instead of enforcing contracts, it dictated; instead of promoting the welfare of the population, it impoverished and depopulated. Moreover, while the East India Company was not a proper government, it was not a proper mercantile body either, because, having usurped sovereign power, it had abandoned commercial principles. It was indifferent to the prices paid on the open market; it engaged in systematic breach of contracts; it had poor and fraudulent accounting, bringing upon it insolvency, improvident borrowing, and ruined credit $\left(9^{\text {th }} \mathrm{R}, 242-3\right)$. In short, "no trace of equitable government is to be found in their politics; not one trace of commercial principle in their mercantile dealings" (FB, 432-3).

A remaining question is why Burke parted ways with Smith on the problem of colonies, despite their shared vexation with mercantile sovereignty and their broad affinity on matters of domestic political economy. Smith's approach to colonial questions remained consistently liberal from abstract principle, which placed him amongst the more unequivocal critics of empire. His ideal solution to what he perceived to be a colossal waste of resources and distorted economic development in the old "colonial system" was radical decolonization and free trade between independent states. Seeing the naïve implausibility of such a call, he put forward the (equally unrealistic) option of an imperial federation of free trade, whose seat of government would shift around the empire in accordance with the fiscal contribution of each province. ${ }^{59}$ Going a step forward, one could argue that the ideal of free trade and peaceful commerce that Smith pitted against the mercantile regulations of his time was itself an abstract 
construct, born out of his critique of the extant overseas trading practices that invariably wedded military force to commercial enterprise. ${ }^{60}$ Burke stood closer to a different vision of global politics that deemed the Navigation Laws to be the cornerstone of colonial policy, and embraced empire for economic reasons that were arguably more pressing for a statesman like Burke than for a philosopher like Smith. The striking alacrity with which Burke incorporated the Indian dominions into the British Empire ${ }^{61}$ should be sought as much in reasons of imperial political economy as in the better-known providentialist and constitutionalist justifications. ${ }^{62}$ As early as 1775 , Burke alerted his parliamentary audience to the meteoric rise of the Atlantic colonial commerce and its centrality to British prosperity (SC, 112-6). Similarly, he introduced Indian dominions to the House as "[t]he greatest body of your revenue, your most numerous armies, your most important commerce, the richest source of your public credit" (NA, 491), and underscored the "interest which this nation [Britain] has in the commerce and revenues of that country" (FB, 381). In contrast to Smith, Burke leaned towards the mercantilist principles of promoting free trade within imperial borders and fostering "plenty" as the "sinews of power," which had become political common sense by the end of the eighteenth century. ${ }^{63}$ As Marshall notes,

The deepening commitment to empire by British government was driven above all by a sense of insecurity. Insecurity was rooted in fear of France ... Empire played a very important part in this long confrontation with France. The long-distance trades, predominantly carried on within a framework of imperial regulation, were thought to generate the maritime resources and a crucial part of the wealth that enabled Britain to hold her own. ${ }^{64}$

Given the perceived indispensability of empire for national survival, prosperity, and reputation, it comes as no surprise that Burke spurned Josiah Tucker's calls for decolonization as childish (SC 128), and repudiated Smith's criticism that colonial trade "has drawn the juices from the rest of the body" (SC, 114). Burke skepticism of global free trade was not exceptional. Patrick O'Brien reminds us that

very few critics of mercantilism and Imperialism writing between 1688 and 1815 developed an alternative blueprint for national development. ... Nearly everyone at the time perceived that economic progress, national security, and the integration of the kingdom might well come from sustained levels of investment in global commerce, naval power, and, whenever necessary, the acquisition of bases and territories overseas. $^{65}$ 
Accordingly, Burke's remedy for mercantile sovereignty eschewed decolonization and called for the institutional improvement of the Indian administration in the spirit of bureaucratic professionalism and probity, foreshadowing the reforms enacted by the Cornwallis government after Pitt's 1784 India Bill.

\section{Dialectics of commerce}

The Company, this sovereign-mercantile manticore, strayed from Burke's commercial ideal not only in terms of economic policy but also in moral values of civilization. It might at first appear strange to see Burke referring to the British exploits in India as "barbarous," given his sense of Britain as "the most enlightened of the enlightened part of Europe" (SOI, 315). Nonetheless, the frequency with which the term appeared in Burke's discourse indicates that its use was not accidental. In his "Speech on Almas Ali Khan," Burke referred to Indians as "millions of our fellow-creatures ... whom our barbarous policy had ruined" (AA, 463), and he poured scorn on the Company agents' actions as "barbarities" of an "inhuman system" (AA, 471). Two years later, he once again assailed Hastings's policies as "crimes of barbarity" (POH, 65). Considered in terms of the Scottish Enlightenment categories that influenced Burke's thought, ${ }^{66}$ British behavior in India represented a civilizational regress from the civility of commercial society to the barbarism of nomadic societies. ${ }^{67}$ This relapse found expression in Burke's indignation at the youth of most of the East India Company servants, who neither had the chance to grow roots in Britain, nor had the intention to do so in India, in effect rendering them vagrant marauders, "birds of passage and prey" who descended in waves upon that hapless country (SOI, 286-90, FB, 402).

On the frontiers of the empire, British men acted like roving frontiersmen, a term that can be applied with theoretical force to the British imperial formation more generally. Burke himself had evoked a similar imagery in his "Speech on Conciliation" (1775), delivered at the height of the political crisis with the Thirteen Colonies. Opposing proposals for restricting further English settlement in North America, he warned the House of Commons that the colonists would ultimately defy the limits and settle beyond the Appalachians, but in the process "they would change the manners with the habits of their life; would soon forget a government by which they were disowned; would become Hordes of English Tartars; 
and, pouring down upon your unfortified frontiers a fierce and irresistible cavalry, become masters of your Governors and Counsellors" (SC, 129). Polished manners would fall from Englishmen as they left the institutional order and civilizing influence of Christianity and social hierarchy. While in America this civilizational distance would issue from the settlement of the outback, in India it would result from the remoteness of the country from the British metropole, a problem that Burke mentioned repeatedly. To continue the analogy, survival in an alien natural environment in North America would force the Englishmen to lose the refined manners of civilized life, and become the "rugged frontiersmen" of Frederick J. Turner's thesis. Similarly, the alien cultural environment in India would instill anxiety, fear, and revulsion in Englishmen, driving them to isolate themselves from Indians, develop harder and sterner attitudes, and lose all possibility of sympathy with those people whom they ruled and oppressed. ${ }^{68}$

Taken together, these remarks on the American and Indian empires indicate that for Burke the imperial frontier was a dangerous space, where gentlemen turned into frontiersmen, civility degenerated into barbarism, polished manners dissipated in the violent grab for land and riches. ${ }^{69}$ The problem, however, was that the British Empire that Burke embraced could expand by no other means than the exploits of the frontiersmen in America and India. The colonial frontier, with its attendant moral abominations from a metropolitan perspective, was not an anomaly but had been the very modus operandi of imperial expansion that underpinned British power and prosperity. ${ }^{70}$ It was thanks to the unruly colonists in America, slave raiders in Africa, planters in the West Indies, and the Company men in India that the economic surplus, the fruits of colonial primitive accumulation poured into Britain and made the "gentlemanly capitalism" of the metropole possible. ${ }^{71}$ Per Burke's suggestion, Britain could have reestablished a "truly commercial" relation to India but only at the cost of a massive negative balance of trade, as had been the case until the East India Company (as "providence" would have it) reversed it by deploying extra-economic violence and violating the "just principles of commerce." 72

Most importantly, the barbarity that Burke perceived in the conduct of the Company was neither that of the marauding Tartars or Goths, though this was the only vocabulary of barbarism available to him, nor that of the rude and warlike ancient citizens as Pocock and Richard Bourke argue, ${ }^{73}$ but one that 
lurked within the commercial society itself. The barbarism that erupted in India was not a relapse into the “conquering spirit of arrogant nobility" which had been tamed into polished manners by religion and prescription. It was a new kind of barbarism fueled by the natural "desire of acquisition," by the principle of self-interest that was supposed to be "calm and dispassionate," by that "reasonable, powerful, and prolifick principle" of "laudable avarice" that was the "grand cause of prosperity." In the colonies, these economic and moral principles turned into their opposites: the desire of acquisition turned into "peculation;" calm and dispassionate self-interest turned into violent "rapacity;" laudable avarice turned into "sordid avarice;" the prosperity they ought to have created turned into "ruination" and "depopulation." These were the precise terms in which Burke systematically condemned the East India Company. On the imperial frontier in India, Englishmen did not turn into Tartars, they became banians.

Banians were the native servants of Englishmen in India, who also acted as commercial agents on behalf of their masters. Burke's opinion of banians bordered on loathing. In his “Speech on Fox's India Bill," he described banians as creatures "whose fathers they [Indian nobility] would not have set with the dogs of their flock" (FB, 426). During the impeachment, he warned the House that if Indianism were suffered to dominate British politics, the British nation would "become a Chain of Twisters, prevaricators, dissemblers Liars, a nation of Banians" $\left(6^{\text {th }} A, 62\right)$. Banians were "habituated to misery and subjection, can submit to any orders, and are fit for the basest services. Having been themselves subject to oppression ... they are fit to oppress others" (SOI 292). In the service of Englishmen "the Banyan extorts, robs, and murders" (SOI 293). The idea of the banian embodied for Burke the sacrifice of morality at the altar of self-interest, the reduction of all social relations to temporary association for pecuniary aggrandizement, the dissolution of human sociability as such in the ether of vulgar material gain. This dynamic was represented, first, in the collusion of the Nawab of Arcot with Benfield and his "cabal of creditors," which ended up ruining the inhabitants of the Carnatic. Burke denounced this collusion as a "magnificent plan of universal plunder" and labeled the creditors "the determined enemies of human intercourse itself" (NAD, 516-8; emphases added). The second incarnation of the social dissolution was the "system of banyans" in Bengal in general, and Hastings's relation to his banian in particular. In this system, money was the only 
interracial glue that bound people who otherwise had not, and would probably never have, an iota of human sociability between them. In other words, the banian embodied the dark underside of the very principles of self-interest and contractual freedom. These principles reached their extreme form in the colonies, whereby they turned into their opposites and became the solvents of society as such.

The odium of Indianism that the "banian" embodied in the colony the "nabob" condensed in the metropole. Burke's speeches after 1783 variously express the fear that the peculation and avarice born of colonial capitalism on the subcontinent would come home to roost. In his speech on Fox's India Bill, Burke depicted the returned Company servants "loaded with odium and with riches" as a pestilence that infiltrated the body politic of the English elite: "they marry into your families; they enter into your senate; they ease your estates by loans; they raise their value by their demand" (FB 443, 403). The note of urgency in these words would reach a crescendo in Burke's speech on the Sixth Article of Impeachment: "These people pour in upon us everyday. They not only bring with them the wealth they have, but they bring with them into our country the vices by which they were acquired" $\left(6^{\text {th }} \mathrm{A}, 62\right)$. New barbarians awaited at the gates to "let loose all the corrupt wealth of India acquired by the oppression of that country to the corruption of all liberties ... today the Commons of Great Britain prosecute the delinquents of India. Tomorrow, the delinquents of India will be the Commons of Great Britain" $\left(6^{\text {th }} A, 62-3\right)$.

As the frontispiece quotation that opens this essay implies, therefore, it was not capitalism (men of mobile wealth, moneyed interest, public credit) but colonial capitalism (imperial frontiersmen, unabashed plunder, violence, and oppression) that Burke found threatening to his image of society and civilization as such. In the colonies, commercial society revealed its other, violent noncommercial underside. An indirect triangulation of the "dialectics of commerce," and a window onto the vicissitudes of colonial capitalism is thus part of the heritage that Burke has bequeathed to political theory.

\section{Conclusion}

This essay has focused on a specific aspect of the interface between Burke's economic and imperial ruminations, namely, the colonial inversion of Burke's commercial ideal in India. Burke's efforts 
to reform the Indian government indicate his belief that "imperial commerce" (as opposed to "imperious commerce") was possible under the British rule of law. ${ }^{74}$ Whether this was indeed the case is a question of historical research and theorization that exceeds the scope of this essay, though I have tried to provide some preliminary remarks in this direction within the framework of colonial capitalism. ${ }^{75}$ Most importantly, I have attempted to show that colonial capitalism as an analytic frame can shed new light on some of the tensions and ambiguities in Burke's thought, and enhance the interpretive texture of the existing Burke scholarship. I have highlighted from a colonial perspective the pattern of political economy in the elaborate tapestry of Burke's thinking, which is woven from sociological theories of historical development and institutional evolution, psychological and aesthetic ruminations, and moral and political philosophy. In Capital, Karl Marx labeled Burke a "vulgar bourgeois through and through.," 76 The foregoing discussion has established, I hope, that if Burke's political economy exhibited "bourgeois" colors, these were much more complex and variegated than Marx was ever willing to grant.

The analysis presented here opens up new lines of inquiry for intellectual history and political theory. Why did Burke shower sympathy on the Indians while evincing little compassion for African slaves and open disdain for Native Americans? O’Neill has provided one possible answer by arguing that that India qualified as a "civilization" on a par with Britain mainly by virtue of its institutionalized religion and established aristocracy. I think one could proceed further along the axis of political economy by asking to what extent socioeconomic complexity could serve as the wedge to pry open the vexed relationship between reason and civilization in Burke's thought. After all, the signature characteristic of "commercial society" was its unprecedented economic complexity, "interest, habit, and the tacit convention that arise from a thousand nameless circumstances" (S, 126; emphases added), which denied the possibility of a panoptic and omniscient perspective from which it could be grasped, and rendered it almost a sublime totality. Hampsher-Monk captures this problem well when he argues that for Burke "political society" was a "miraculous" assemblage of institutions, rules, moral beliefs, customs, habits, and dispositions. ${ }^{77}$ Systemic harmony in a social formation of such magnitude and intricacy could not possibly be the result of deliberate design, which leads Bromwich to the conclusion that for Burke 
“society" was a "work of art without a maker.",78 Burke's remarks on India, especially in his "Speech on Fox's India Bill," imply that he perceived it as a commercial society in the Scottish Enlightenment sense of the term, a point that could find additional support from the affinity between Burke's and William Robertson's views of Indian society. ${ }^{79}$ Against this background, one might consider a revisionist thesis: it was not reason per se that Burke wanted to humble before tradition and custom, and admonish in India as well as in France, but it was reason that made the hubristic claim to regulate or revolutionize the aweinspiring complexity of commercial society - a humility that evaporated when the object of reason was the socioeconomic simplicity of savage societies in America or barbarous societies in Africa. ${ }^{80}$

A second question regards the historical origins of property and order in Burke's thought. It has been noted that Burke admitted the originary conquest behind all political order and the expropriation at the fount of all property. ${ }^{81}$ Legitimacy accrued to power and property with time and prescription, and these origins were not to be readily exposed at times of discontent. In his "Speech on Opening of Impeachment," Burke declared, "there is a secret veil to be drawn over the origins of all governments" (SOI, 316-7) - a point that would recur in his celebration of the parliament of 1688, which "threw a wellwrought veil over every circumstance tending to weaken the rights [of the king to the throne], which ... they meant to perpetuate" (R, 69-70). Whelan thoughtfully suggests that imperious British rule in India threatened to unveil the violent and irregular origins of government both in India and in Britain. ${ }^{82}$ Conceptualizing colonial India as a mirror to the violent origins of English political and economic order promises insights into questions of founding violence and criminal violence, constitutive power and the rule of law, and legality and legitimacy in Burke's thought. One comes across glimmers of these questions in his diatribe against Hastings: Burke labeled Hastings as "the great criminal [who] has the law in his hands" (SOI, 290), compared him to the inmates of the Newgate Gaol and apologized to the latter for "dishonoring" them with "such an odious comparison" (SPI, 459) (a point echoed in his characterization of the principles behind the French Revolution as too "scandalous" and "shocking" even for the criminals in Newgate [R, 121]), and insisted that Hastings be tried at the bar of "natural, immutable and substantial justice" rather than by the British common law (SOI, 276). David Armitage 
contends that imagining the "Second [i.e. Eastern] British Empire" as an empire of conquest has served to efface the initial phase of conquest and empire-building in the British Isles. ${ }^{83}$ A careful analysis of Burke's anxieties over the Second British Empire could help retrace such effacements.

Finally, I hope that the movement between political theory and intellectual history that I have tried to perform here serves as an invitation to constructing syncretic interdisciplinary frameworks for tackling profound historical and theoretical concepts such as liberalism, capitalism, and colonialism especially at those moments where intellectual history, political economy, and post-colonial literary criticism as disciplinary conventions turn into spaces of confinement for the insights they generate.

\section{NOTES}

${ }^{1}$ These two debates, of course, do not come near capturing the range of interpretive frames that have been applied to Burke's thought. For an informative overview of perspectives on Burke, see Daniel I. O’Neill, The Burke-Wollstonecraft Debate: Savagery, Civilization, Democracy (University Park: Pennsylvania State University Press, 2007), pp. 51-3.

${ }^{2}$ Frederick Cooper and Ann Laura Stoler, "Between Metropole and Colony: Rethinking a Research Agenda" in Cooper and Stoler, eds., Tensions of Empire: Colonial Cultures in a Bourgeois World (Berkeley: University of California Press, 1997), p. 4.

${ }^{3}$ I should emphasize that imperial political economy is only one amongst the multiple vectors of Burke's attack on the East India Company, which include charges of undermining the constitutional order, political morality, and national character in Britain, and crimes of oppression, illegality, and violations of higher laws of justice in India.

${ }^{4}$ All of the primary texts cited in the essay are from Paul Langford (ed.), The Writings and Speeches of Edmund Burke (Oxford: Clarendon Press, 1981). The primary texts cited in this essay and their abbreviations are as follows: Third Letter on a Regicide Peace $\left(3^{\mathrm{rd}} \mathrm{L}\right)$; The Ninth Report of the Select Committee $\left(9^{\text {th }} \mathrm{R}\right)$; Speech on the Sixth Article of Impeachment $\left(6^{\text {th }} \mathrm{A}\right)$; Speech on Almas Ali Khan (AA); Address to the Colonists (AC); Speech on Economic Reform (ER); Speech on Fox's India Bill (FB); 
Letter to A Noble Lord (LNL); Speech on Nabob of Arcot's Debts (NAD); Speech on the Motion for Papers on Hastings (POH); Reflections on the Revolution in France (R); Thoughts and Details on Scarcity (S); Speech on Conciliation with America (SC); Speech on Opening of Impeachment (SOI); Speech on Pitt's Second India Bill (SPI); Tracts Relating to Popery Laws (TPL).

${ }^{5}$ C. B. Macpherson, Burke (New York: Hill and Wang, 1980), p. 21, 55. Macpherson reconciles Burke's conservatism and defense of capitalism by arguing that the order he tried to uphold was already capitalist. ${ }^{6}$ J. G. A. Pocock, "Tangata Whenua and Enlightenment Anthropology," in The Discovery of Islands: Essays in British History (Cambridge: Cambridge University Press, 2005), p. 204.

7 J. G. A. Pocock "Political Economy of Burke's Analysis of the French Revolution," in Virtue, Commerce, History: Essays on Political Thought and History, Chiefly in the Eighteenth Century (Cambridge: Cambridge University Press, 1985), pp. 194-6. For Pocock, Burke's thought is representative of the shift from ancient republican to modern commercial attitudes on political economy. Characteristic of the latter was the positive-sum view of commerce, which, as Steve Pincus has compellingly shown, distinguished the Whig political economic vision that hinged on labor, productivity, and boundless economic growth from land-based conceptions of wealth and finite material enrichment. Along similar lines, Frederick Whelan observes in Burke's thought an "enthusiastic embrace of the modern commercial society" of which Britain was the leading exemplar, and a commitment to the idea of self-regulating markets. Steven Pincus, 1688: The First Modern Revolution (New Haven, CT: Yale University Press, 2009), esp. chap. 12; Frederick G. Whelan, Edmund Burke and India: Political Morality and Empire (Pittsburgh, PA: University of Pittsburgh Press, 1996), pp. 96-7.

${ }^{8}$ Jerry Z. Muller, "Edmund Burke: Commerce, Conservatism, and the Intellectuals," in The Mind and the Market: Capitalism in Modern European Thought (New York: Alfred A. Knopf, 2002).

${ }^{9}$ Gertrude Himmelfarb, The Idea of Poverty: England in the Early Industrial Age (New York: Alfred A. Knopf, 1984), p. 67-9. One should note in passing that even this interpretation of Burke's position on the laboring poor, on which most interpreters agree, does not go unchallenged, as Jennifer Pitts discerns in 
Burke's image of the British polity a "defense of the poor." Jennifer Pitts, A Turn to Empire: The Rise of Liberal Imperialism in Britain and France (Princeton, NJ: Princeton University Press, 2005), p. 94.

${ }^{10}$ P. J. Marshall "Edmund Burke and India: The Vicissitudes of a Reputation," in Politics and Trade in the Indian Ocean World, ed. Rudrangshu Mukherjee and Lakshmi Subramanian (Oxford: Oxford University Press 1998), p. 258.

${ }^{11}$ David Bromwich, "Introduction," in On Empire, Liberty and Reform: Speeches and Letters, ed. David Bromwich (New Haven, CT: Yale University Press, 2000), p. 20. For Bromwich, the source of Burke's anxieties is modernity in general, as he stresses amongst the "tendencies of modern life that Burke most fears" the reorganization of life "for the sake of money or efficiency or abstract rights." Ibid, p. 37.

${ }^{12}$ Iain Hampsher-Monk, "Edmund Burke and Empire," in Lineages of Empire: The Historical Roots of British Imperial Thought, ed. Duncan Kelly (Oxford: Oxford University Press, 2009). Hampsher-Monk maintains that the "laws of trade" invoked by Burke should be understood as referring to the "existing mercantile regulations, not to the abstract conclusions of political economy appealed to by Smith." Ibid, p. 131. Margaret Kohn and Daniel O’Neill likewise observe "Burke's love of free trade seems to have been circumscribed to companies internal to the British Empire.” Margaret Kohn and Daniel I. O'Neill, “A Tale of Two Indias: Burke and Mill on Empire and Slavery in the West Indies and America," Political Theory 34 (2006): 192-228, p. 203.

${ }^{13}$ Iain Hampsher-Monk, "Introduction" in The Political Philosophy of Edmund Burke, ed. Iain HampsherMonk (New York: Rowman, 1987), pp. 11-16.

${ }^{14}$ Donald Winch, Riches and Poverty: An Intellectual History of Political Economy in Britain, 1750-1834 (Cambridge: Cambridge University Press, 1996), chap. 7.

${ }^{15}$ Isaac Kramnick, The Rage of Edmund Burke: Portrait of an Ambivalent Conservative (New York: Basic Books, 1977).

${ }^{16}$ Bernard Semmel, The Rise of Free Trade Imperialism: Classical Political Economy, the Empire of Free Trade and Imperialism, 1750-1850 (Cambridge: Cambridge University Press, 1970), pp. 20-4. 
${ }^{17}$ Himmelfarb, Idea of Poverty, p. 73.

${ }^{18}$ Hampsher-Monk, "Edmund Burke and Empire," pp. 131-2.

19 P. J. Marshall, "Introduction," in The Writings and Speeches of Edmund Burke, Vol. 7, ed. P. J. Marshall (Oxford: Clarendon Press, 1981), p. 13. Marshall emphatically distinguishes Burke's "vision of world-wide empire based on universal justice" from that of the Enlightenment critics of empire, like Smith, Kant, and Condorcet, who aspired for universal brotherhood through commerce. P. J. Marshall, "Burke and Empire," in Hanoverian Britain and Empire: Essays in Memory of Philip Lawson, ed. Richard Connor, Clyve Jones, and Stephen Taylor (Woodbridge: Boydell Press, 1981), pp, 266, 298; Marshall, "Edmund Burke and India,” p. 266.

${ }^{20}$ Whelan, Edmund Burke and India, pp. 20-3.

${ }^{21}$ O’Neill, Burke-Wollstonecraft Debate, pp. 40-5, 83-7; Kohn and O’Neill, “Tale of Two Indias,” pp. 205.

${ }^{22}$ The convergence is unexpected because Mehta's Liberalism and Empire: A Study in NineteenthCentury British Liberal Thought (Chicago, IL: University of Chicago Press, 1999) condemns liberalism across the board as an inherently imperialist political philosophy. Pitts's A Turn to Empire, in contrast, sets out to salvage the eighteenth-century Enlightenment from such charges as Mehta's, by delineating within it a temporary, yet clearly identifiable, anti-imperialist movement.

${ }^{23}$ Mehta, Liberalism and Empire, pp. 26, 30-1, 41-3, 157-8.

${ }^{24}$ Pitts, A Turn to Empire, pp. 60-1, 68-74, 96-8.

${ }^{25}$ Daniel I. O’Neill, “Rethinking Burke and India,” History of Political Thought 30 (2009): 492-523.

${ }^{26}$ Sarah Suleri, The Rhetoric of English India (Chicago, IL: University of Chicago Press, 1992), p. 26, 46.

${ }^{27}$ Nicholas Dirks, The Scandal of Empire: India and the Creation of Imperial Britain (Cambridge, MA: Belknap, Harvard University Press, 2006), p. 29, 125, 314, 333.

${ }^{28}$ Manu Goswami, Producing India: From Colonial Economy to National Space (Chicago, IL: University of Chicago Press, 2004), p. 13. 
${ }^{29}$ For a useful overview of such material incentives in the seventeenth century, see Nuala Zahedieh, Capital and the Colonies: London and the Atlantic Economy, 1660-1700 (Cambridge: Cambridge University Press, 2010), and in the eighteenth century, see C. A. Bayly, The Imperial Meridian: The British Empire and the World, 1780-1830 (New York: Longman, 1989).

${ }^{30}$ I should emphasize that the notion of empire should not to be understood as the nation-state writ large on the globe, but as a network of hetereogeneous and hierarchical localities with correspondingly different political forms of governance and legal structures, specialized economic activities, cultural milieus, and social status within the imagined imperial totality. For a good overview of imperial socioeconomic and institutional heterogeneity, see Andrew Porter, "Introduction," in The Oxford History of the British Empire Vol. 3, ed. Andrew Porter (Oxford: Oxford University Press, 1999). See also Ann Laura Stoler, "Imperial Formations and Opacities of Rule," in Lessons of Empire: Imperial Histories and American Power, ed. Craig Calhoun, Frederick Cooper, Kevin Moore (New York: New Press, 2006).

${ }^{31}$ David Armitage, The Ideological Origins of the British Empire (Cambridge: Cambridge University Press, 2000), p. 173.

32 Jennifer Pitts, "Political Theory of Empire and Imperialism," Annual Review of Political Science 13 (2010): 211-35, p. 220.

${ }^{33}$ For the deindustrialization of Indian textile production, see Hameda Hossain, The Company Weavers of Bengal: The East India Company and the Textile Production in Bengal, 1750-1813 (Delhi: Oxford University Press, 1988). For the Permanent Settlement, see Guha, A Rule of Property for Bengal, and Eric Stokes, The English Utilitarians and India (Oxford: Clarendon Press, 1959). For the commercialization of agriculture, see Rajat Datta, Society, Economy, and the Market: Commercialization in Rural Bengal, . 1760-1800 (New Delhi: Manohar, 2000).

${ }^{34}$ Andrew Sartori lucidly summarizes the imbrication of coercion and capital in the commercialization of Indian agriculture in this period: "The cultivators were thus already positioned de facto as wage laborers producing surplus out of the capital of the planters. Advances functioned as wages foisted upon the 
cultivator through either the force of necessity (want of cash) or direct coercion (the threat of dispossession through rent enhancement or naked violence), and forcibly depressed to such a level as to ensure so that the product thus secured would return surplus value." Andrew Sartori, Bengal in Global Concept History: Culturalism in the Age of Capital (Chicago, IL: University of Chicago Press, 2008), p. 57. Subjugation of the peasant mode of production in India to the imperatives of capital accumulation and the proliferation and intensification of unfree forms of labor are widely investigated in postcolonial Indian historiography. For such two excellent works, see Gyan Prakash, Bonded Histories: Genealogies of Labor Servitude in Colonial India (Cambridge: Cambridge University Press, 1990), and Jairus Banaji, "The Fictions of Free Labour: Contract, Coercion, and the So-Called Unfree Labour," Historical Materialism 11 (2003): 69-95. Also see, Kenneth Pomeranz and Steven Topik, The World that Trade Created: Society, Culture, and the World Economy, 1400-the Present (Armonk, NY: M. E. Sharpe, 1999).

${ }^{35}$ Karl Marx describes "primitive accumulation" as divorcing direct producers from the conditions of labor through the deployment of political and legal violence, or more broadly, severing laborers' relatively immediate access to the means of subsistence and production. Primitive accumulation thus comprises the processes whereby relations of social reproduction are reconstituted according to the logic of capital accumulation. In a fleeting yet important passage, Marx gestures at the global expanse of primitive accumulation in the consolidation of capitalist relations and highlights the role of colonialism on three continents: "The discovery of gold and silver in America, the extirpation, enslavement and entombment in mines of the aboriginal population of that continent, the beginnings of the conquest and plunder in India, and the conversion of Africa into a preserve for commercial hunting of blackskins, are all things which characterize the dawn of the era of capitalist production. These idyllic proceedings are the chief moments of primitive accumulation." Karl Marx, Capital: A Critique of Political Economy, Vol. 1 (London: Penguin, 1976), p. 915 (emphasis added).

${ }^{36}$ For the genealogy of this political economic vision, see Pincus, 1688, chap. 12. Burke appears to have shared in the Whig political economic worldview that grasped commerce as a positive-sum game, as he 
criticized zero-sum conceptions of trade in a letter to a friend. "It is in the interest of the commercial world that wealth should be found everywhere. I know that it is but too natural for us to see our own certain ruin in the possible prosperity of other people. ... Trade is not a limited thing; as if the objects of mutual demand and consumption could not stretch beyond the bounds of our Jealousies." Burke, Two Letters from Mr. Burke to Gentlemen in the City of Bristol, quoted in Muller, "Edmund Burke," p. 115.

${ }^{37}$ True to his Whig heritage, Burke hitched agricultural improvement to the prospect of profit. "Every law against property is a law against industry," and such laws in Ireland were tantamount to proclaiming, “Thou shalt not improve." (TPL, 476-7).

38 A well-governed, "true oeconomy ... is a distributive virtue, and consists not in saving, but in selection" (LNL, 162). These words corroborate Pocock's observation that Burke's definition of political virtue was based on the management of public revenue rather than martial prowess, which made him a defender of commercial society and the Whig aristocratic government that promoted it. See Pocock, "Political Economy of Burke's Analysis" p. 209.

${ }^{39}$ Adam Smith, An Inquiry Into the Nature and Causes of the Wealth of Nations, R. H. Campbell and A. S. Skinner (eds) Vol. II of the Glasgow Edition of the Works and Correspondence of Adam Smith (Indianapolis: Liberty Fund, 1981), book II, chap. 3, par. 28.

${ }^{40}$ Albert Hirschman, The Passions and the Interests (Princeton, NJ: Princeton University Press, 1997), esp. pp. 41, 53-62.

${ }^{41}$ Burke offered an account of this transformation in his aborted project, An Abridgment of English History. For a discussion of this work and its relevance for Burke's political philosophy, see Richard Bourke, "Edmund Burke and the Politics of Conquest," Modern Intellectual History, 4 (2007): 403-432.

${ }^{42}$ Winch notes that despite his approval of unproductive consumption by nobility and clergy, Burke took for granted the Smithian assumption that the source of economic prosperity was productive labor, frugality, saving and investment. Winch, Riches and Poverty, pp. 194-7. 
${ }^{43}$ J. G. A. Pocock, "Burke and the Ancient Constitution," in Politics, Language, and Time: Essays on Political Thought and History (New York: Atheneum, 1971); Iain Hampsher-Monk, "Introduction”; F. P. Lock, Edmund Burke (Oxford: Clarendon Press, 1998), esp. Vol. 1, chap. 12.

${ }^{44}$ Unfortunately, Burke left no substantial tract or speech on the English enclosures. The only relevant remarks, which are mostly in passim, can be found in his unpublished letters entitled 'Mnemon to the Public Advertiser' (Writings and Speeches, Vol. 2, pp. 75-87). Burke's position in these letters is not very clear, though it seems broadly in line with his economic reform proposals, with additional concerns with the rights of the poor and equity of the process. See Francis Canavan, The Political Economy of Edmund Burke: The Role of Property in His Thought (New York: Fordham University Press, 1995), pp. 118-9.

${ }^{45}$ The natural entitlement of the capital owner to a profit on his capital was restated in Burke's defense of the moneyed property $\left(3^{\text {rd }} \mathrm{L}, 346-7\right)$.

46 David McNally, Political Economy and the Rise of Capitalism: A Reinterpretation (Berkeley: University of California Press, 1988).

${ }^{47}$ For the theological language in Burke's political economy and its fatalistic implications for the poor, see Winch, Riches and Poverty, pp. 212-8, and Himmelfarb, Idea of Poverty, pp. 67-8. I agree with Winch's remark that we need not question the sincerity of Burke's theological explanations of socioeconomic hierarchy. Neither do we have to follow this point, however, to the conclusion that Burke therefore could not harbor liberal-capitalist allegiances. In fact, the discursive arsenal that Burke variously employed to defend his political economic views was rather syncretic, combining ancient constitutionalism, physiocratic tenets, Augustinian notions of the great chain of being, and arguments from natural jurisprudence. This is not surprising, as eighteenth-century political economy "served as more than a technocratic blueprint for achieving opulence" and essentially constituted "a new kind of moral economy" with substantially different first principles. Winch, Riches and Poverty, p. 165; Himmelfarb, Idea of Poverty, p. 46. As I discuss below, for Burke religious belief constituted one of the major threads in the noncommercial fabric of social discipline that made possible commercial relations. 
${ }^{48}$ See Pocock, "Political Economy of Burke's Analysis" pp. 196-9, 210; Winch, Riches and Poverty, pp. 176-9; O’Neill, Burke-Wollstonecraft Debate, chaps. 1 and 2.

${ }^{49}$ Muller, "Edmund Burke" p.137-8.

${ }^{50}$ One should not overstate the difference between Burke and Smith on principles of authority, deference, and hierarchy. Smith himself espoused a formidable notion of natural hierarchy and shared Burke's antagonism toward neo-Lockean theories of natural right. See Winch, Riches and Poverty, pp. 173-7.

${ }^{51}$ I am very much in debt of an anonymous reviewer from Polity for this crucial insight.

${ }^{52}$ See Pocock, "Political Economy of Burke’s Analysis."

${ }^{53}$ For example, Bromwich boils the imperial problem for Burke down to the inconsistency and "selfdeception in every act of domination.” Bromwich, Introduction, p. 33.

54 “The maxims of Thoughts and Details on Scarcity are equally the maxims of the Ninth Report." P. J. Marshall, The Writings and Speeches of Edmund Burke, Vol. 5, ed. Paul Langford (Oxford: Clarendon Press, 1981), p. 195. Burke was also a close friend of Philip Francis, a prominent British physiocrat and Burke's principal informant on Indian affairs. Francis's economic ideas would stamp Fox's India Bill (1783), and inform the Permanent Settlement in Bengal (1793). See Guha, A Rule of Property for Bengal. ${ }^{55}$ On empire and free trade, see Canavan, Political Economy of Edmund Burke, p. 122.

${ }^{56}$ P. J. Marshall, "English in Asia to 1700," in The Oxford History of the British Empire, ed. Nicholas Canny (Oxford: Oxford University Press, 1998).

${ }^{57}$ A more detailed account of this strategy is in "Speech on the Nabob of Arcot's Debts," pp. 536-7.

${ }^{58}$ An exemplary account is in the "Speech on the Sixth Article of Impeachment," where Burke weaves out of the East India Company's clandestine political dealings with Mohammed Reza Khan, Nandakumar, and Munni Begum a story of total corruption, disobedience, and violation of human trust.

${ }^{59}$ Wealth of Nations, book IV, chap. 7, par. 79. For a lucid treatment of Smith's position on the colonial system, see Winch, Riches and Poverty, pp. 137-44. For the consistent anti-imperialism of Smith, see Pitts, A Turn to Empire, chap. 2. 
${ }^{60}$ Instructive in this vein is a pamphlet that defends the East India Company against Smith's attacks. In $A$ Candid Examination of the Reasons for Depriving the East India Company of its Charter (1779), Julius Mickle noted that armed trading companies had been endemic to the known history of European trade with the East Indies. A survey of the Portuguese and Dutch exploits in South and Southeast Asia made it "rash, even childish, to talk of the ease and advantage of free trade with the Eastern world" and clear that "commerce in India could not be carried without garrisons and warlike fleets" (p. 13, 15). Pincus notes that from the seventeenth century onwards, there existed a consensus in England that "trade in Africa as in the East Indies could never be a purely commercial endeavor" and forts and ships of war were necessary for trade with "barbarous and heathen people [and] other nations [in] the vicious world of international trade." Pincus, 1688, p 375. For the conflicting commitments to global commerce and sovereign interest in the eighteenth century, see Emma Rothschild, "Global Commerce and the Question of Sovereignty in the Eighteenth Century Provinces," Modern Intellectual History, 1 (2004): 3-26. For a sympathetic treatment of Adam Smith's critique of chartered companies and his proleptic notion of global commerce, see Sankar Muthu, “Adam Smith’s Critique of International Trading Companies. Theorizing Globalization in the Age of Enlightenment," Political Theory 36 (2008): 185-212.

${ }^{61}$ Marshall, "Burke and Empire,” pp. 290-1.

${ }^{62}$ For the providentialist elements, see P. J. Marshall, "Introduction" in The Oxford History of the British Empire, Vol. 6, pp. 25-7. For a view from "imperial constitution," see Robert Travers, "Contested Despotisms: Problems of Liberty in British India," in Exclusionary Empire: English Liberty Overseas, 1600-1900, ed. Jack P. Greene (Cambridge: Cambridge University Press, 2010), pp. 200-1. For primary evidence, see the "Speech at the Opening of Impeachment," pp. 281-2.

${ }^{63}$ John Brewer, The Sinews of Power: War, Money and the English State, 1688-1783 (New York: Alfred A. Knopf, 1989); Pincus, 1688, pp. 388-9. Mercantilism is a notoriously vague notion and often pitted against mature "capitalism." The perspective on the colonial and global inceptions of capitalism that I adopt here rejects this facile dichotomy. Mercantilism or the "old colonial system," which hinged on the 
deployment of the organized power of the British state, constituted less an aberrant political intervention in global commerce than the politico-legal conditions of the seventeenth- and eighteenth-century networks capital movement and accumulation. Mercantilism was not so much an antithesis of global commerce as the historical framework within which "commerce" could emerge as historical reality and object of contemplation in the first place. An excellent recent study that demonstrates the formative link between mercantilism and global capital accumulation is Zahedieh's Capital and the Colonies.

${ }^{64}$ P. J. Marshall, “Introduction,” in A Free Though Conquering People?, (Ashgate: Variorum, 2003), p. x. ${ }^{65}$ Patrick K. O’Brien, “Inseparable connections: Trade, Economy, Fiscal State, and the Expansion of Empire, 1688-1815" in The Oxford History of the British Empire Vol. 2, ed. P. J. Marshall (Oxford: Oxford University Press, 1998), p. 76. Also see Pincus, 1688, pp. 369-71.

${ }^{66}$ The biographical and intellectual connection between Burke and the Scottish Enlightenment is compellingly demonstrated in O'Neill, Burke-Wollstonecraft Debate, chap. 2.

${ }^{67}$ For a magisterial discussion of the civilizational categories of the Scottish Enlightenment, see J. G. A. Pocock, Barbarism and Religion, Vol. 4 (Cambridge: Cambridge University Press, 2005).

${ }^{68}$ To America and India, one must add Ireland. Nicholas Canny has shown that Ireland served as the historical laboratory in which English practices of colonization and discourses of barbarism were developed, and later transported to America and India. As is well known, restoring equal rights to Ireland's Catholic inhabitants living under the yoke of the Protestant Ascendancy constituted one of Burke's life-long personal yearnings and political endeavors. For the processes alienation and aggression in India, see Jon E. Wilson, “Anxieties of Distance: Codification in Early Colonial Bengal,” Modern Intellectual History 4 (2007): 7-23, and The Domination of Strangers: Modern Governance in Eastern India 1780-1835 (Basingstoke: Palgrave MacMillan, 2008), chaps. 2 and 3. For Ireland, see Nicholas Canny, "The Permissive Frontier," in Kenneth Andrews, Nicholas Canny, Paul Hair, and David Quinn, The Westward Enterprise: English Activities in Ireland, the Atlantic, and America, 1480-1650 (Detroit: 
Wayne University Press, 1979), and "Introduction," in The Oxford History of the British Empire Vol. 1, ed. Nicholas Canny (Oxford: Oxford University Press, 1998).

${ }^{69}$ The moral-civilizational problems posed by the colonial frontier were extensively elaborated upon in eighteenth-century French social thought, as Anthony Pagden demonstrates. Burke's studies on India represent perhaps the first critique of the English frontier that matches its French counterpart in empirical expanse and theoretical depth. Anthony Pagden, Lords of All the World: Ideologies of Empire in Spain, Britain, and France, c. 1500- c. 1800 (New Haven, CT: Yale University Press, 1995), pp. 165-8

${ }^{70}$ For the economic importance of Indian territorial revenues, see Bayly, Imperial Meridian, introduction.

${ }^{71}$ For a comprehensive account of gentlemanly capitalism in the British Empire, see P. J. Cain and A. G. Hopkins, British Imperialism: Innovation and Expansion, 1688-1914 (New York: Longman, 1993). The intimate yet uneasy connection between the gentlemen and the frontiersmen of empire is also observed by Hannah Arendt in The Origins of Totalitarianism (New York: Harcourt, 1968), p. 130.

${ }^{72}$ Drain of wealth qua "export of bullion" from Europe to Asia had been the norm until around the mideighteenth century and inflamed intense debate amongst political economists since early 1600s. Seventeenth-century classics in this debate are Thomas Mun's A Discourse of Trade from England unto the East Indies (London, 1621) and Sir Josiah Child's A Treatise Concerning the East India Trade (London, 1681). William Robertson addressed the same question in his A Historical Disquisition on the Knowledge, and the progress of trade with that country prior to the discovery of the passage to it by the Cape of Good Hope (London, 1792). The fulcrum of Robertson's argument was the reversal of Europe's fortunes by the quasi-providential discovery of Americas and the circumnavigation of the Cape, which made Europe the epicenter of a global commercial network and enabled it to withstand the Ottoman pressure. Given that Robertson was the foremost Scottish Enlightenment influence on Burke's conception of world history, there are plausible grounds to assume that their historical visions converged. For the Robertson-Burke connection, see O’Neill, Burke-Wollstonecraft Debate 42-5, 80-2. 
${ }^{73}$ J. G. A Pocock, "The Mobility of Property and the Emergence of Eighteenth Century Sociology," in Virtue, Commerce, and History (Cambridge: Cambridge University Press, 1985), pp. 114-5; "Political Economy of Burke’s Analysis," pp. 195-6; Bourke, "Edmund Burke and the Politics of Conquest."

${ }^{74}$ As a figure of contrast, for example, David Hume openly admitted that a liberal corporatist form of metropolitan government would inevitably wreak oppression and plunder in its colonial domains. Burke, on the other hand, tried to disavow this pessimistic link. See, Hume, "That Politics May be Reduced to a Science" in Essays, Moral and Political (1742).

${ }^{75}$ Partha Chatterjee, for instance, maintains the impossibility of the commercial ideal in the face of the irreducible "imperial presence" and therefore the political relationship of subjugation and unfreedom in India. Matthew Connelly more broadly defines "the essence of empire" as "the exercise of untrammeled power," unaccountable and incompatible with the rule of law. Partha Chatterjee, The Nation and Its Fragments: Colonial and Postcolonial Histories (Princeton, NJ: Princeton University Press, 1993), pp. 10-8; Matthew Connelly, “The New Imperialists” in Lessons of Empire, ed. Calhoun et al., p. 32.

${ }^{76}$ Marx, Capital Vol. 1, p. 925-6 n13.

${ }^{77}$ Hampsher-Monk, "Introduction,” p. 35.

${ }^{78}$ Bromwich, "Introduction,” pp. 36-7.

${ }^{79}$ See Robertson, Historical Disquisition, Appendix.

${ }^{80}$ Whelan agrees with O’Neill on Burke and Robertson's shared reverence for the Indian civilization but objects to his argument that Burke held Amerindians in disdain. Whelan's Burke is more ambiguous on Amerindians, unwilling to denigrate them absolutely, yet unable to sympathize with their primitive ways due to "limits of intercultural comprehension." Frederick G. Whelan, Enlightenment Political Thought and Non-Western Societies: Sultans and Savages (London: Routledge, 2009), pp. 167-8.

${ }^{81}$ Canavan, Political Economy of Edmund Burke, p. 68; Winch, Riches and Poverty, p. 180.

${ }^{82}$ Whelan, Edmund Burke and India, p. 229.

${ }^{83}$ Armitage, Ideological Origins, chap. 1. 